\title{
RESEARCH PAPER \\ Pilot study for feeding preferences and grazing behavior in two breeds of sheep on a secondary succession of the Chiloé Archipelago
}

\author{
María A. Gallardo ${ }^{1}$, Rubén Pulido ${ }^{1}$, Rodrigo de la Barra², and María E. \\ Martínez ${ }^{2}$ \\ 'Escuela de Graduados, Facultad de Ciencias Veterinarias, Universidad Austral de Chile. Casilla 567, \\ Valdivia, Chile. \\ ${ }^{2}$ Instituto de Investigaciones Agropecuarias. O’Higgins 415-A oficina 14, Chiloé, Chile.
}

\begin{abstract}
M.A. Gallardo, R. de la Barra, and M.E. Martínez. 2014. Pilot study for feeding preferences and grazing behavior in two breeds of sheep on a secondary succession of the Chiloé Archipelago. Cien. Inv. Agr. 41(2):249-254. A pilot study was undertaken to determine the pattern of feeding preferences and grazing behavior of the Chilota breed of sheep in the Chiloé Archipelago. First, eight Chilota and eight Suffolk Down ewes were faced with different numbers of plant species (offered only for $10 \mathrm{~min}$ ), after fasting and after grazing a calafatal, a secondary succession dominated by shrubs. The experiment was repeated four times within a period of $22 \mathrm{~d}$ and included a 1-month pre-experimental period. Second, six Chilota and six Suffolk Down ewes, randomly selected from the same groups, were placed to graze on a calafatal divided into three 10 -by- $10 \mathrm{~m}$ paddocks to facilitate rotation of the animals. Observations were performed for 1 minute at 1-hour intervals for 11 hours a day, over 10 consecutive days, recording the following behaviors: grazing, browsing, resting, ruminating, and grooming. Regarding the dry matter intake of each of the three plant species present in all trials (B. chilensis, G. mucronata and D. winteri), results showed D. winteri was the most consumed and B.chilensis the least. The grazing behavior showed grazing was the main activity recorded for both breeds (especially for Suffolk Down) during the morning and evening, while resting and ruminating were the main activities recorded during the warmest hours. In summary, the breeds showed similar preferences but different grazing behavior pattern on a secondary succession of the Chiloé Archipelago.
\end{abstract}

Key words: Calafatal, Chilota, grazing behavior, preferences.

\section{Introduction}

Sheep introduced to the Chiloé Archipelago in Chile during the Spanish colonization period, had a strong impact on the vegetation. Their

Received November 12, 2013. Accepted May 25, 2014 Corresponding author: mugallar@gmail.com subjection to the agroecological conditions, along with the long period of isolation and inbreeding, led to genetic and ethnological differentiation in the introduced animals, which are currently recognized as the Chilota breed of sheep (De la Barra et al., 2010). Background data indicate that this breed has characteristics suited for grazing on poor quality forage, such as a small body 
size and adaptations of their limbs (De la Barra et al., 2008).

In the Chiloé Archipelago, the main food resource for ruminants is a secondary succession (shrublands, called calafatal) derived from anthropic intervention of the native forest coupled with the introduction of sheep during regrowth. This system is dominated by shrubs such as Berberis chilensis L. and B. microphylla G. Forst; some trees, such as Drimys winteri J.R. Forst \& G. Forst; ferns, such as Blechnum penna marina; and herbaceous plants, such as Agrostis capillaris, Holcus lanatus L. and Trifolium repens L., among others (Gallardo et al., 2014).

Considering that sheep production is based mostly on pasture lands, such as the calafatal, this study was designed to determine the feeding preferences and grazing behavior of Chilota sheep. Our hypothesis is that the Chilota breed of sheep, as a result of an adaptive process, should have higher shrub consumption and, therefore, browsing times than other breeds recently introduced to Chiloé.

\section{Materials and methods}

The experiment was conducted at the Butalcura Research Center, Chiloé-Chile, located between $41^{\circ} 44^{\prime}$ and $43^{\circ} 17^{\prime}$ South latitudes, and between $72^{\circ} 45^{\prime}$ and $74^{\circ} 30^{\prime}$ 'West longitudes, during January and February of 2011.

\section{Feeding preferences pilot study}

For this experiment, eight Chilota $(57 \pm 4.1 \mathrm{~kg}$ live weight, LW) and eight Suffolk Down (64 \pm $4.8 \mathrm{~kg} \mathrm{LW}$ ) sheep, with similar body condition scores $(\mathrm{BCS}=3.5)$ and at least one lambing, were randomly selected from a large, free flock grazing on a calafatal.

The plant species used, which were not considered a supplement due to the small amount offered and the short duration of the offering (10 min), were Trifolium repens, Holcus lanatus, Blechnum penna-marina (Poir.) Kuhn, Berberis microphylla, Gaultheria mucronata (L.f.) Hook \& Arn., and D. winteri. Three $300 \mathrm{~g}$ samples of each vegetable species were collected for analysis, using a randomly selected $0.1 \mathrm{~m}^{2}$ ring from each calafatal paddock at the beginning and at the end of the experiment. The chemical analyses of the plant species were performed at the Remehue Experimental Station to determine dry matter (DM) content, crude protein (CP), metabolizable energy (ME) and neutral detergent fiber (NDF), according to the method described in Gallardo et al. (2014).

Four treatments with different numbers of plant species (6, 5, 4 and 3) were designed, starting with six species and removing a plant species each day. Plant species were removed in the opposite order of appearance in the secondary succession (first were the arboreal species such as $D$. winteri, then shrubs such as G.mucronata and B.chilensis, ferns such as B.penna-marina and finally herbs such as H.lanatus and T.repens (De la Barra, 2008)). These experiments were performed after $12 \mathrm{~h}$ of overnight fasting (AF) and after $3 \mathrm{~h}$ of grazing (AG) the calafatal. The experiment was conducted 4 times for $3 \mathrm{~d}$ durations, followed by a rest period of $3 \mathrm{~d}$ between experiments. The assay duration was $22 \mathrm{~d}$; the experiments were preceded by an adjustment period of $30 \mathrm{~d}$.

A cattle shed with a slotted floor was used to shelter the animals at night. A test pen with an even floor $(8 \times 5 \mathrm{~m})$ was used for experimental purposes. Thirty numbered headless feeders $(20 \times 20 \mathrm{~cm})$, positioned $10 \mathrm{~cm}$ above the floor and containing 5 replicates of each plant species, were located near both sides of the test pen. Twelve hours before the assay, each plant species was manually collected from a calafatal paddock and stored at $5{ }^{\circ} \mathrm{C}$. The quantity of each species offered was adjusted to fit the volume of the feeder: $45 \mathrm{~g}$ of T. repens and D. winteri, $35 \mathrm{~g}$ of H. lanatus and B. penna-marina, $30 \mathrm{~g}$ of G. mucronata and 25 
$\mathrm{g}$ of B. chilensis. Before each trial, plants were randomly allocated to different numbered feeders. Once each trial ended, each feeder was weighed to obtain the group's consumption per breed. To calculate the biomass intake, corrections for evaporative weight loss were made by weighing leaves and branches that were not used in the trials, both before and after each trial.

In the morning (AF), ewes were separated by breed and were subsequently allowed to enter the test pen (as a group, according to breed). Each animal could freely select the plant species from the feeders. The trials lasted 10 minutes; the trials were repeated in the afternoon (15:00 h) after three hours of grazing. After the second trial, sheep were again allowed to graze until 21:00 h. Ewes had free access to water sources.

\section{Grazing behavior pilot study}

Six Chilota $(55 \pm 0.9 \mathrm{~kg}$ live weight, LW) and six Suffolk Down $(61 \pm 2.1 \mathrm{~kg} \mathrm{LW})$ ewes with similar BCS (3.5) were randomly selected from the same groups used in the first experiment and were identified using a number on their backs. Three $10 \times 10 \mathrm{~m}$ paddocks in the calafatal were used. Ewes were separated by breed (using mesh) in the same paddock, giving each the same available vegetation conditions. Animals were rotated every three days, according to low DM availability (approximately $763 \mathrm{~kg} \mathrm{DM} \mathrm{ha}^{-1}$ ), measured from the soil levels during the measuring month. Ewes had free access to water sources. At night, a cattle shed with a slotted floor housed the animals and protected them from predators.

After a 10-day period of adjustment to the experimental conditions, an evaluation of grazing behavior was performed over a $10-d$ period. The ewes were observed and video recorded for a 1-min period within each $\mathrm{h}$ for 11 consecutive $\mathrm{h}$ a day between 9:00 and 20:00 h. The assay was repeated over 10 consecutive days resulting in a complete record of the following activities: grazing (ewes consuming forage from pasture), browsing (ewes consuming leaves and branches from shrubs), resting (ewes lying), ruminating (ewes lying and ruminating), interacting (social interaction) and grooming (ewes standing and lying while auto-grooming in the field). Activities were recorded digitally, using a hidden 3-by-2 m scaffold to avoid exerting any influence on their behavior.

\section{Statistical analysis}

Because this was a pilot study, we used only descriptive statistics (mean $\pm \mathrm{SEM}$ ).

\section{Results}

B. chilensis and G. mucronata, along with D. winteri showed higher DM proportions compared to T. repens and H. lanatus. Both, however, showed the highest $\mathrm{CP}$ and ME proportions compared to G. mucronata and D. winteri (Table 1).

Table 1. Chemical analysis of the different vegetable species presented to the animals ${ }^{1,2}$.

\begin{tabular}{lccccc}
\hline & DM & CP & ME & NDF & "D” \\
\cline { 2 - 6 } Plant species & \multicolumn{5}{c}{ LSM \pm SEM $(\mathrm{n}=6)$} \\
\hline Trifolium. repens & $15.06 \mathrm{~d} \pm 2.09$ & $26.88 \mathrm{a} \pm 0.36$ & $2.73 \mathrm{a} \pm 0.01$ & $29.72 \mathrm{f} \pm 0.48$ & $75.48 \mathrm{a} \pm 0.29$ \\
Holcus lanatus & $13.45 \mathrm{~d} \pm 0.36$ & $21.48 \mathrm{~b} \pm 0.21$ & $2.60 \mathrm{~b} \pm 0.02$ & $59.48 \mathrm{a} \pm 0.41$ & $71.30 \mathrm{~b} \pm 0.59$ \\
B. penna-marina & $21.72 \mathrm{c} \pm 0.58$ & $11.53 \mathrm{~d} \pm 0.70$ & $1.17 \mathrm{~d} \pm 0.03$ & $51.60 \mathrm{~b} \pm 0.65$ & $27.43 \mathrm{f} \pm 0.82$ \\
Berberis microphylla & $35.73 \mathrm{a} \pm 1.03$ & $14.00 \mathrm{c} \pm 0.25$ & $2.27 \mathrm{c} \pm 0.02$ & $38.97 \mathrm{~d} \pm 0.54$ & $61.17 \mathrm{c} \pm 0.57$ \\
Gaultheria mucronata & $36.67 \mathrm{a} \pm 0.88$ & $6.80 \mathrm{f} \pm 0.09$ & $1.40 \mathrm{f} \pm 0.04$ & $43.25 \mathrm{c} \pm 0.93$ & $34.53 \mathrm{e} \pm 1.15$ \\
Drimys winteri & $27.62 \mathrm{~b} \pm 0.69$ & $9.13 \mathrm{e} \pm 0.10$ & $1.53 \mathrm{e} \pm 0.02$ & $34.37 \mathrm{e} \pm 1.18$ & $38.32 \mathrm{~d} \pm 0.60$ \\
\hline
\end{tabular}

${ }^{1}$ B.penna-marina (Blechnum penna marina); dry matter (DM, \%); crude protein (CP, \%); metabolizable energy (ME, MJ kg-1); neutral detergent fiber (NDF, \%), "D" value. ${ }^{2}$ Different small letters denote a significant effect of the plant species $(\mathrm{P} \leq 0.05)$. 
For the three species (B. chilensis, G. mucronata and $D$. winteri) that participated in all trials (Figure 1), Chilota ewes had a lower dry matter intake (DMI) for shrub species (B. chilensis and G. mucronata) than Suffolk Down ewes in almost all trials. This trend was less evident in the trial with 6 species. In both breeds of sheep, results suggest a lower DMI of $B$. chilensis and higher DMI of $D$. winteri. The two breeds of ewes did not show differences in DMI between trials. $T$. repens, $H$. lanatus and $B$. penna-marina (which were only used in one, two and three trials, respectively) showed the same trend of lower DMI for the Chilota than for Suffolk Down ewes. A higher DMI (after fasting and then grazing) was only found in the trial with five species (data not shown).

Regarding the grazing behavior, the main activities from 9:00 to 20:00 $\mathrm{h}$ are illustrated in Figure 2. Our results suggest that both breeds, especially the Suffolk Down, grazed mainly in the early morning and evening hours. Browsing (especially after 17:00 h) and grooming activities were recorded more often in Chilota than in Suffolk Down ewes, but resting and ruminating activities were observed more frequently in Suffolk Down than in Chilota ewes.

\section{Discussion}

In this study, the number of plant species erratically influenced the DMI according to breed. Wang et al. (2010) reported that the breed effect on intake preference became more evident when the number of plant species was less than six.

The lower DMI recorded for the Chilota than for the Suffolk Down ewes could be explained by their smaller body size (De la Barra et al., 2008) and voracious consumption in comparison to the Suffolk Down breed. Considering the DMI of $B$. chilensis, G. mucronata and D. winteri (which were present in all trials), $D$. winteri was the most preferred, despite being one of the least nutritious species, with a low $\mathrm{CP}$ and ME content (Allegretti et al., 2012). It is necessary to consider other factors, such as palatability and specific leaf area (Lloyd et al., 2010). Thus, compared to B. chilensis (the least consumed and therefore the least preferred), D. winteri exhibited lower levels of DM, CP, ME and NDF. The presence of thorns could be an important factor explains its infrequent selection.

The study was carried out during summer time. Results show that both breeds grazed mainly in the early morning and evening hours when

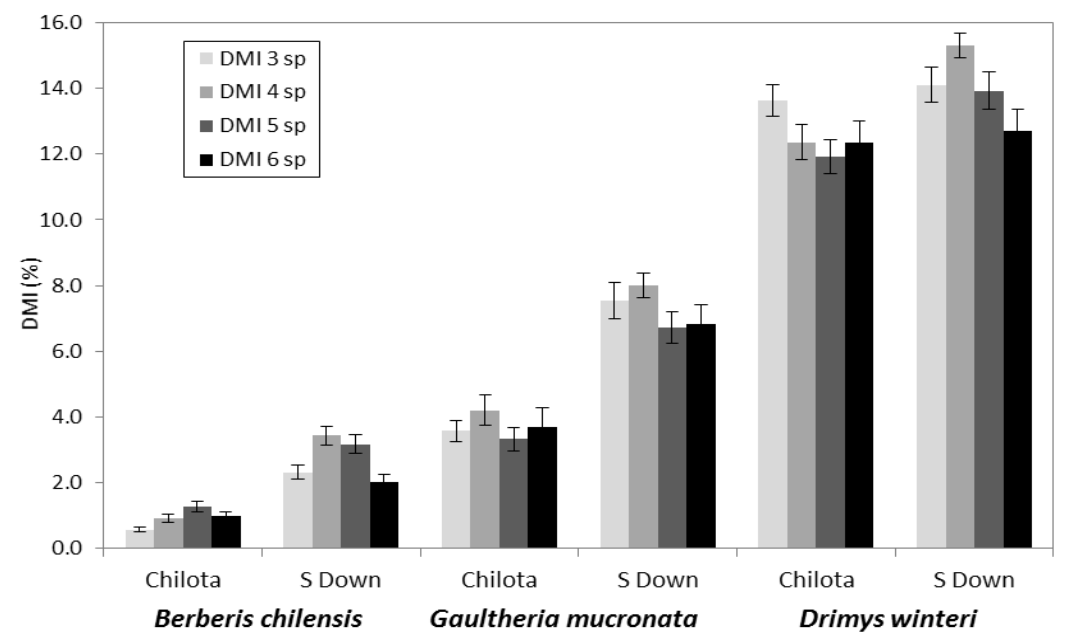

Figure 1. Pattern of feeding preferences in two breeds of sheep measured through DMI (AF plus AG) for each of the three individual species present in all the trials (B. chilensis, $G$. mucronata and D. winteri). DMI 3sp: dry matter intake considering 3 vegetable species; DMI 4 sp: dry matter intake considering 4 vegetable species; DMI 5 sp: dry matter intake considering 5 vegetable species; DMI 6 sp: dry matter intake considering 6 vegetable species. 
A)

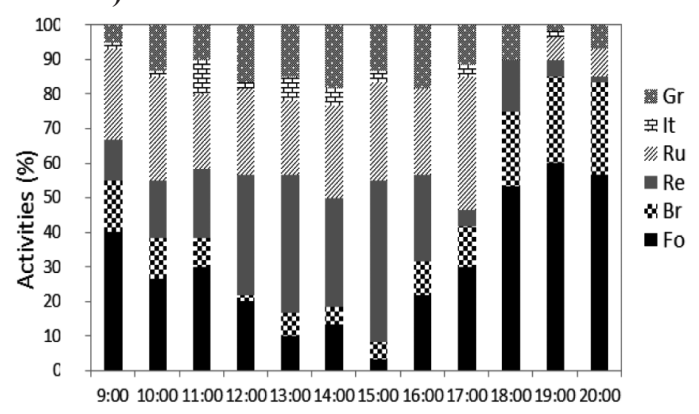

B)

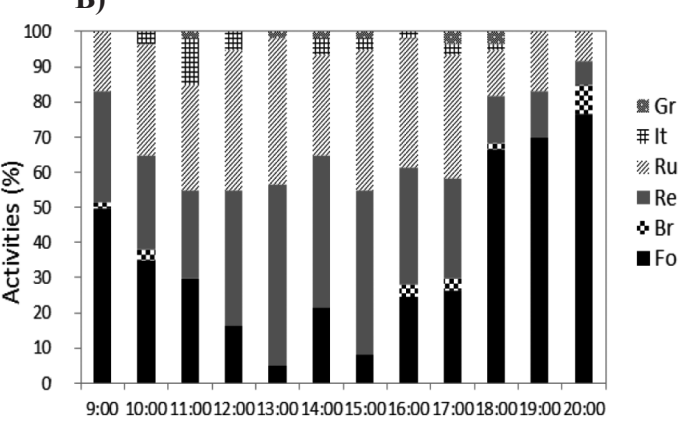

Figure 2. Main activities recorded during the daytime (descriptive data): grooming (Gr), interaction (It), ruminating (Ru), resting (Re), browsing (Br) and grazing (Fo) in Chilota (A) and Suffolk Down breeds (B).

temperatures were relatively mild. The Chilota breed, a native one, is likely to be better suited to the calafatal than are the other sheep genotypes present in Chiloé. This breed has a small body size and some adaptations in its limbs (such as relative weight and rate of cane) that facilitate grazing of more rustic and poorer quality forage (De la Barra et al., 2008), explaining why browsing activity was recorded more often for the Chilota compared to the Suffolk Down ewes.

The main activities observed during the warmest hours were resting or ruminating, which were most likely ways to avoid overheating. Lin et al. (2011) evaluated the effect of different grazing intensities on grazing behavior in a fat-tailed sheep breed and reported the existence of two main grazing periods: a shorter period in the morning and a longer one during the afternoon. This greater preference for diet consumption in the afternoon could be explained by the higher digestibility compared with that of fodder harvested in the morning (Burns et al., 2005). In summary, both breeds showed similar feeding preferences and different grazing behavior pattern.

\section{Resumen}

M.A. Gallardo, R. Pulido, R. de la Barra y M.E. Martínez. 2014. Estudio piloto para preferencias y comportamiento en pastoreo en dos razas ovinas sobre una sucesión secundaria del Archipiélago de Chiloé. Cien. Inv. Agr. 41(2):249-254. Un estudio piloto fue realizado para determinar el patrón de preferencias y comportamiento en pastoreo de la raza ovina Chilota en el Archipiélago de Chiloé. Primero, ocho ovejas Chilota y ocho Suffolk Down fueron enfrentadas a diferente número de especies vegetales (no consideradas como suplemento), ofrecidas sólo por 10 min post-ayuno y post-pastoreo de un calafatal, una sucesión secundaria dominada por arbustos. El experimento fue repetido cuatro veces en un lapso de 22 d, considerando además un período pre-experimental de un mes. Posteriormente, seis Chilota y seis Suffolk (aleatoriamente seleccionadas desde los mismos grupos) fueron ubicadas para pastorear un calafatal dividido en tres potreros de $10 \times 10 \mathrm{~m}$ para poder rotar los animales. Las observaciones fueron realizadas por 1 minuto, a intervalos de 1-hora por 11 horas diarias, durante $10 \mathrm{~d}$ consecutivos, registrando diferentes comportamientos, tales como: pastoreo, ramoneo, descanso, rumia, interacción y acicalamiento. Considerando la ingesta de materia seca de cada una de las tres especies presentes en todos los desafíos (B. chilensis, G. mucronata y $D$. winteri), los resultados mostraron que $D$. winteri fue la más consumida y $B$. chilensis, 
la menos consumida. El comportamiento en pastoreo mostró que el pastoreo fue la principal actividad registrada para ambas razas (especialmente en Suffolk Down) durante la mañana y la tarde, mientras descanso y rumia fueron las principales actividades durante las horas de mayor calor. En resumen, ambas razas mostraron similar patrón de preferencias, aunque diferente comportamiento en pastoreo en una sucesión secundaria de Chiloé.

Palabras clave: Calafatal, Chilota, comportamiento en pastoreo, preferencias.

\section{References}

Allegretti, L., C. Sartorb, S. Paez Lamaa, V. Egeaa, M. Fucili, and C. Passera. 2012. Effect of the physiological state of Criollo goats on the botanical composition of their diet in NE Mendoza, Argentina. Small Rum. Res. 103:152- 157.

Burns, J.C., H.F. Mayland, and D.S. Fisher. 2005. Dry matter intake and digestion of alfalfa harvested at sunset and sunrise. J. Anim. Sci. 83:262-270.

De la Barra, R, M.E. Martínez, C. Gonzalo, and F. San Primitivo. 2008. Ovino Criollo Chilote. II caracteres morfoestructurales. IX Simposio sobre Conservación y utilización de recursos zoogenéticos. Buenos Aires, Argentina. p. 223-226.

De la Barra, R., H. Uribe, E. Latorre, F. San Primitivo, and J. Arranz. 2010. Genetic structure and diversity of four chilean sheep breeds. Chilean J. Agric. Res. 70:646-651.
Gallardo, M.A., M.J. Rivero, and L. Faúndez. 2014. The grazing behavior and diet selectivity of two lamb breeds on secondary successional pastures in the Chiloé Archipelago. Livestock Sci. 161:69-79.

Lin, L., U. Dickhoefer, K. Müller, Wurina, and A. Susenbeth. 2011. Grazing behaviour of sheep at different stocking rates in the Inner Mongolian steppe, China. Appl. Anim. Behav. Sci. 129:36-42.

Lloyd, K., M. Pollock, N. Mason, and W. Lee. 2010. Leaf trait-palatability relationships differ between ungulate species: evidence from cafeteria experiments using naïve tussock grasses. New Zealand J. Ecol. 34:219-226.

Wang, L., D. Wang, Z. He, G. Liu, and C. Hodgkinson. 2010. Mechanisms linking plant species richness to foraging of a large herbivore. J. Appl. Ecol. 47:868-875. 